\title{
Contextualizing Efforts at Increasing Socioeconomic Participation in the Context of Jordan
}

\author{
Dr. Mohammad Husni Abumelhim \\ Associate Professor \\ Al-Balqa' Applied University \\ Ajloun University College \\ Sociology and Social Work \\ As-Salt, Jordan
}

\begin{abstract}
This research article analyzed the effects of Jordanian laws on empowerment issues as related to Jordanian women who live in rural areas of the country. Particularly, it examined the traditional gender roles for women in light of access to essential services including education, health and employment, and also in light of the types of aid various service providers are giving within rural communities.
\end{abstract}

Keywords: Sociology of Development, rural areas, Jordanian women, service providers

\section{Introduction}

The financial states of Jordanian women have continuously been at the front line of themes of social change in Jordan (Abumelhim, 29). This is much more so the case given the political change that has occurred as of late. With a huge measure of writing coming to surface on issues that the Jordanian women face as a group, when all is said in done face and also challenges that Jordanian women specifically are looked with, this consider went for analyzing the financial states of the last inside the system of the male-centric authority and also NGOs presently at work in making social change. Despite the fact that factual information was obsolete and lacking in accessibility, this examination utilized data accumulated from the Department of Statistics and additionally the United Nations Improvement Program to represent the number of inhabitants in Jordanian women as far as socioeconomics in request to better survey their financial circumstance as well as the progressions that they are as of now experiencing as an aftereffect of current political, and lawful change.

\section{Disaggregation of Social Characteristics of Jordanian Women in Rural Areas}

Rural territories comprises of all territories between 700-1,100 meters above ocean level that get under $200 \mathrm{~mm}$ of water/year- $80 \%$ of general Jordanian domain. Jordan's general geological region is $89,318,000$ square kilometers with a normal of $68.8 \%$ individuals per 2 square kilometers. The aggregate Jordanian populace is $6,309,963-82.6 \%$ urban and $17.4 \%$ rustic. Provincial land is normally utilized by Women'ss for goat crowding and cultivating (Housing and Populace Statistics, 2012). Jordanian women include $48.5 \%$ of the aggregate populace. Northern Jordan, covering 26,435 square kilometers, is separated into three provinces: the northeastern locale, the northwestern district, and Ruwaishid. These provinces comprise of nine regions: Salhia, Sabha, Um Al-Jimal, Um Al-Qutain, Dair Al-Kahif (the Northeastern district), Sama Al-Sirhan, Husha, and Khaledia (the Northwestern district), and Ruwaishid. The aggregate populace of Northern Jordan is 146, 250 (2/7 of the aggregate nation's populace also, 55\% of every single provincial region). Square kilometers per capita are more noteworthy than Central and Southern Jordan since it has more appropriate ecological conditions and better street benefit regarding vicinity to bigger urban areas. Jordan's focal district, covering 10,000 square kilometers, is partitioned into two areas: Muwaqar and Jeeza. These regions comprise of four regions: Jeeza, Muuwaqar, Rujum Al-Shami, Um Al-Rasas. The add up to populace is 74,660 (1/3 of Jordan's aggregate populace what's more, $28.2 \%$ of every single country zone). Despite its substantial domain, the focal area has a little square kilometer for every capita in examination with different areas at 3.6\%. Maybe this is because of the pervasiveness of mechanical assembling in the locale, as the focal area is known to have high work profitability. The Southern district, not at all like the North, has troublesome natural conditions and needs appropriate street benefit what's more, general framework, abandoning it with just 3 individuals per square kilometer. 


\section{Increasing Socioeconomic Participation}

There are many variables that have prompted an adjustment in Jordanian women's social position, the most critical of which is mobilization. Mobilization joined together Jordanian women into a strong political and monetary power. Jordanian women who joined into one settlement created nearer ties than they had amid the premobilization period. Settlement caused speedy change in the Jordanian Women's women's life as far as her social part. For instance, power and running water diminished the work that she had initially performed. Instructive foundations and wellbeing offices raised her level of wellbeing and training.

She additionally turned out to be more mindful of her general surroundings through media. "Lamentably a quick and uncommon change in the style of life carried with it numerous issues. It is went with a wide range of issues: an ascent of neediness, wrongdoing, joblessness. Yet, there is additionally a beneficial outcome - Women'ss get an entrance to the cutting edge medicinal services, instruction, and a little and immaterial increment to the privileges of Women's women" (Women's, 2013). Training is a standout amongst the most critical components that caused an adjustment in the Jordanian Women's social stature and economic wellbeing. More noteworthy school investment was driven, normally, to expanded instruction levels. This all prompted more prominent social, monetary, and political mindfulness for the Jordanian Women's women. These variables empowered her expanded support in the general population life. Financial cooperation outside of the house, instead of interior family unit work, turned into a new concern. She turned out to be more worried about nearby and national issues because of expanded collaboration with NGOs. Settlement assumed an incredible part in expanding Women's worry with formal instruction since it raised their social, financial, and political status. The greater part of this gave Women's young women access to college training and pay that made strides family wage levels (Sarhan). These components made a change in the generalization of the Women's women. Work is associated foundationally with training as a standout amongst the most vital components that prompted a change in the Jordanian Women's women's social part. Work made a difference the Women's women self-realize and leave the singular bounds of customary Women's life by winding up additionally autonomous. The majority of this changed the basic generalization that the Women's women are to stay at home and arrangement exclusively with inward family unit issues, for example, raising youngsters. She came to consider work to be a method by which she can secure her future for herself and her family against troublesome conditions. The improvement of media interchanges, particularly wide utilization of the web, caused extraordinary changes in Jordanian culture in general what's more, in Women's society, specifically. Through media outlets, Women's women turned out to be more mindful of projects that managed guaranteeing women' rights. Media, besides, raised her familiarity with religious, social, wellbeing, and instructive issues. In particular, media gave a gathering for which Women's women could connect in solidarity to different gatherings worried about women' rights. Two imperative angles must be analyzed as far as Jordanian Women's women' education-educational openings and levels of instructive remittance. The Jordanian Women's women today have different instructive capabilities because of the nearness of schools inside closeness to their homes. Furthermore, there are military schools and additionally proficiency establishments that point particularly to enhance Women's women' social circumstance. Disregarding an absence of auxiliary schools and additionally their separation from Women's homes, a portion of the young women were ready to beat these difficulties and go to school. Another test confronting Women's instruction is the need of instructors (particularly female) willing to go educate in provincial zones. The administration, subsequently, is giving financial impetus, for example, higher pay and lodging arrangements to urge educators to instruct in provincial Women's territories. It shows up that the most astounding instruction rates among Women's young women are in the Northern area regardless of the absence of wage and absence of parent's training, and they trust that instruction is security for Women's young women. Advanced education in the North in examination with Central and Southern Jordan is a aftereffect of the previous' being nearer to city life.

\section{Conclusion}

Results unmistakably demonstrate an absence of NGOs that arrangement with Women women' rights. There are few, notwithstanding, counting: The Hashemite Treasury for Rural Advancement, Research and Development Center for Jordanian Rural Areas, the Hashemite Fund for Develoment of Jordan Badia (HFDJP, 2013), the Jordan Stream Foundation, and the Jordan Badia Research and Advancement Program (JBRDP, 2013). 
The most astounding rate of joblessness in Jordan's country Women zones are among women, for reasons including social convention's repressing of work outside of the home, an absence of/low pay, and absence of women' work laws as far as wellbeing protection and insurance from security risks; additionally, work destinations are ordinarily far from Women people group. Likewise, there is an absence of exchange schools to get prepare women with the best possible abilities vital for entering the workforce. On the off chance that we are to defeat these difficulties on a large scale level, we should initially start with the home, in testing the male centric inhibitors that have prompted such unsafe circumstances. NGOs should be urged to take a shot at advancement extends in Women people group, in participation with the Jordanian government. The Government must do its part to guarantee legitimate assurance of Women as far as work laws and medical coverage. Adjust measurable information additionally should be made accessible so that Women women' circumstance can legitimately be surveyed. Just by adequately working towards these dynamic objectives would women be able to women beat social stagnation in the substance of advancement.

\section{Bibliography}

Abumelhim, Mohammad Husni. Women and Social Change in Jordanian Bedouin Society. Studies in Sociology of Science Vol. 4, No. 4, 2013, pp. 27-31 DOI:10.3968/j.sss.1923018420130404.2927

Abu, Samaheh, Mohammed, (2003). Elections and Surprises (online) Available: www.cdfg.org/elections/articles. Al-Hindi, S.\& Dallasheh, A (1990). National Education in Jordan, Dar Alfikr, Amman.

Al- Mousa, Soliman (2003). Social Changes in Jordan (1945-1970), research in: Studies in Jordanian Social History, Dar Sindibad for Printing, Amman.

Al-Tal, Ahmed (1978).Jordanian Educational System Development 1921- 1977 Effects and Factors, Amman.

Kheri, Majdaddean (1985). Social Relations in some Nuclear Jordanian Families; Cooperative Printing Workers Committee , Amman.

Obeidat. M. Taleb,(2008). Highlights of national cultural Jordanian identity, the first conference about national cultural and identity and its role in comprehensive maintenance operation, Al-Thorea Center for Studies, Amman, 8/3/2008.

Obeidat, Soliman(1997).Study in Jordanian Social Habits and Traditions"; Moaray Establishment,Tripoli . 